\title{
Impacts of the conventional tillage tools and reduced tillage on the soil fertility preservation: critical review
}

\author{
REVIEW PAPER
}

\author{
Dayou E. D. ${ }^{\text {* }}$, Zokpodo K. L. B. ${ }^{1}$, Glèlè Kakaï A. L. R. ${ }^{2}$, Ganglo C. J. ${ }^{1}$ \\ 1 School of Environmental Management, Faculty of Agronomic Sciences, University of Abomey-Calavi 01 BP 526 \\ Cotonou, Benin \\ ${ }^{2}$ Laboratory of Biomathematics and Forestry Estimations, Faculty of Agronomic Sciences, University of Abomey-Calavi 04 \\ BP 1525 Cotonou, Benin \\ *Author for correspondences: phreddoss1@yahoo.fr
}

Original submitted in on $2^{\text {nd }}$ August 2017. Published online at www.m.elewa.org on 30th September 2017 https://dx.doi.org/10.4314/jab.v117i1.5

\begin{abstract}
Objective: The long-term impacts of conventional tillage through compaction, soil erosion and loss of soil fertility have led to evaluation of this system. To mitigate these problems, simplified cultivation techniques (SCT) are increasingly practiced. The objective of this review is to clarify the effects of conventional tillage and minimum tillage on soil fertility.

Methodology and Results: The methodology is based on a documentary research through a synthesis and a confrontation of the researches results of different authors. It is found that, after 5 to 6 years, conventional tillage lowers the fertility of the soil and reduces its productivity. There is a diversity of SCT with convincing results. These techniques leave more agricultural residues and allow an improvement of the indicator of organic matter on the soil by reduction of the mineralization. The STC, such as zero tillage, increase soil fertility and have the potential to reduce greenhouse gas emissions. Improving soil fertility increases yield with a saving in working time. Hydraulic conductivity increases when switching from conventional tillage to direct sowing. Compared to conventional tillage, SCT provide an ideal environment for soil fertility recovery. However, the adoption of SCT and no-till is subject to a constraint on the agricultural equipment used. The design of effective equipment remains the challenge to facilitate large-scale application of SCT.

Conclusion and application of results: It is noticed that conventional tillage induce long-term disturbance of soil properties and reduce fertility. Simplified cultivation techniques and particularly a direct sowing have a positive effect on the amount of soil organic matter, its density and water retention, and final production. The specific direct seeder must be designed to accompany the mechanization of these techniques.
\end{abstract}

Keywords: conventional tillage, direct sowing, soil fertility, conservation agriculture.

\section{INTRODUCTION}

In many countries of the world, farmers and researchers have tested various tillage systems to improve land productivity. However, a number of adverse effects on soil properties have accompanied the intensification of these cropping systems and the environment, which have led to a serious questioning of the agricultural techniques used (Bellemou, 2012). In Benin, agricultural production is increasingly 
based on the intensive system. Conventional tillage (mechanical tillage) and application of insecticides and mineral fertilizers are used by producers. Yet, crop yields continue to decline, with declining incomes and food insecurity (Amadji et al., 2007). This shows that this technique of conventional tillage has reached its limits. In fact, conventional tillage causes excessive fragmentation, collapse and compaction of soil. It also generates erosion, run off, impoverishment and drying up of land, thus implying physical deterioration that is sometimes irreversible (Mrabet, 2001a; Abdellaoui et al., 2011). To remedy this, alternative techniques have been developed. These are simplified cultivation techniques or minimum tillage and zero tillage or direct sowing (Kribaa et al., 2001; Lal et al., 2007). In addition to the fact that they replace conventional tillage, SCT refer to a wide range of techniques ranging from superficial tillage to direct sowing under cover of a living crop (Le Garrec and Revel, 2004). These production techniques and mainly direct sowing under vegetation cover reduce soil erosion and

\section{MATERIAL AND METHODS}

For the literature search, several keywords were used to search for publications. These include conventional tillage, minimum tillage, direct sowing, soil conservation techniques, sustainable agriculture, direct seeders, organic matter and carbon in the soil. These publications have been selected in view of their importance to understand the topic developed without any particular criteria of inclusion or exclusion. The most recent work has been privileged. Thus, the articles and other documents consulted are mainly published in the period 2001 to 2015; with however some reference documents from the period 1996 to 1999 . The work carried out by the authors mentioned in this review is carried out on different types of soils and cultures and in various climates. The

\section{RESULTS}

Quantity of residues left on the soil surface: The amount of residue left on the soil varies according to the type of tillage (Table 1). It is observed that the different tillage leave fewer soil residues compared to direct sowing.

Evolution of carbon stocks and organic matter: An experiment carried out by Peigne et al. (2009) shows that increase biomass production and carbon storage (Blanchart et al., 2008). No-till practices are those where the seed is placed directly into the soil with the least amount of tillage possible (FAO, 2011). This technique saves water and provides higher yields than conventional tillage (Bouzza, 1990). Thus, in order to combat the perverse effects of agricultural intensification and the unreasonable use of mechanization, SCT and mainly direct sowing are a promising method from the point of view of soil conservation in general and control soil erosion in particular (Bourarach and Oussiblé, 2001). However, this challenge can only be fully satisfied if direct sowing is practiced with appropriate technology (Mrabet, 2001a). This requires the manufacture of specific seeders capable to succeed this operation. This review highlights the importance of simplified cultivation techniques compared to conventional tillage on soil fertility preservation and the need to innovate effective technologies to facilitate the adoption of these techniques.

treatments studied are conventional tillage, minimum tillage and direct sowing. The tests are carried out during 3 to 6 years of replications. Ploughing equipment consists of a tractor with a plough or a chisel or a cultivator. Sowing is done either with conventional seeders or a direct seeders. The parameters measured on the soil are particle size, bulk density and real density, moisture variation according to depth, soil water retention capacity, amount of soil surface residues; amount of organic matter degraded and stored carbon. On crops, the yield and its components (number of ears, grain weight, biomass produced) were measured. Various measurements were analyzed for variance and correlation tests. The results are given in tables and figures.

the carbon stock $(C)$ of the $0-5 \mathrm{~cm}$ horizon is significantly higher in the first year for very superficial tillage than other techniques (Figure 1). The redistribution of crop residues and possible organic matter $(\mathrm{OM})$ over a shallow soil concentrates the different types of organic matter (residues, microbial biomass, metabolites, stabilized C) in the surface horizons (Andrade et al., 2003). 
Table 1: Quantity of residues kept on the plot using different soil preparation techniques

\begin{tabular}{l|c|c}
\hline Type of soil preparation & Solid debris (\%) & Soft residue (\%) \\
\hline Tillage with the plough & $0-15$ & $0-10$ \\
Plough + chisel & $0-10$ & $0-5$ \\
Discs (2 operations) & $15-20$ & $10-15$ \\
Chisel (2 operations) & $30-40$ & $20-30$ \\
Cultivator (2 operations) & $40-50$ & $30-40$ \\
Cultivator (1 operations) & $50-70$ & $40-60$ \\
Direct sowing & $80-95$ & $60-80$ \\
\hline
\end{tabular}

Source: FAO (2011)

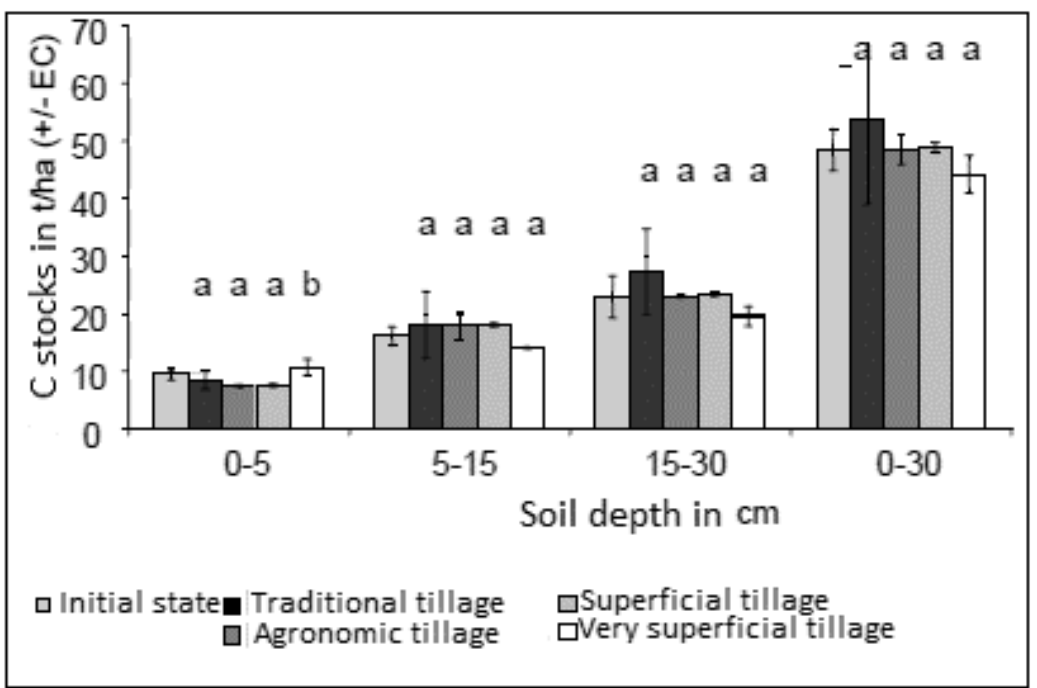

Figure 1: Inventories of $C$ calculated after one year of practice of four tillage techniques $(a, b$ indicates a significant difference with $p<0.05$ ) (Peigne et al., 2009)

Zero tillage techniques conduct to leave organic residues on the soil surface, which slows down the decomposition process, promotes $\mathrm{OM}$ accumulation and consequently improves production capacity. The structure of the unploughed soil improves, allowing the physical protection of soil MO, both by reducing the diffusion of oxygen inside the soil and serving as a physical barrier between the microflora and the substrate. Compared to the conventional tillage system, moisture content increases up to $20 \mathrm{~cm}$ in depth due to the introduction of the direct sowing system, including the first year of study (Table 2).

Table 2: Soil organic matter content in relation to soil management in Mali

\begin{tabular}{c|c|c}
\hline & Direct sowing system & Conventional system \\
\cline { 2 - 3 } & & OM (\%) \\
\hline 0 to 5 & 0.97 & 0.75 \\
0 to 10 & 0.92 & 0.74 \\
0 to 20 & 0.80 & 0.70 \\
20 to 40 & 0.65 & 0.63 \\
40 to 60 & 0.57 & 0.54 \\
60 to 80 & 0.49 & 0.47 \\
80 to 100 & 0.45 & 0.42 \\
\hline
\end{tabular}

Source: Fagaye et al., (2013) 
On the various depths considered, a low OM content was observed under conventional tillage compared to direct sowing. The OM content of the soil affects that of the stored carbon.

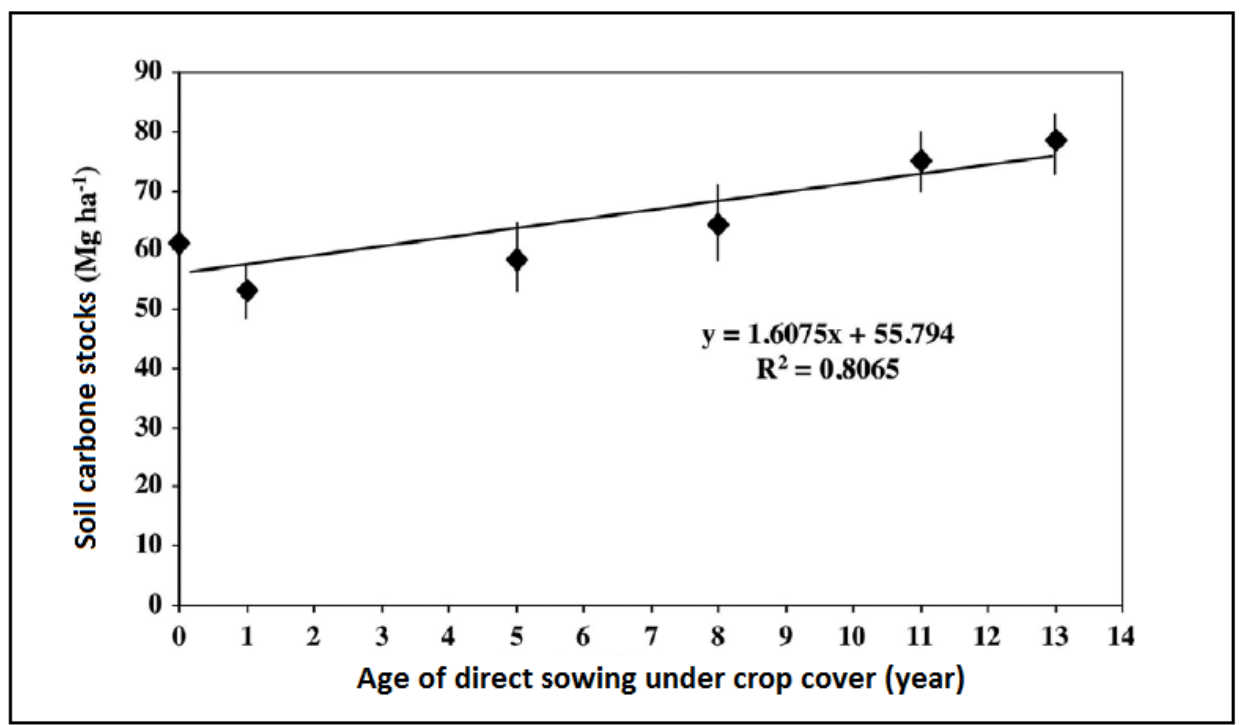

Figure 2: Carbon accumulation rate under direct sowing (Blanchart et al., 2009)

After the third year of cultivation, Abdellaoui et al. (2011) observed a better organic matter content on the first three horizons in zero tillage, ranging from $1.99 \%$ to $1.60 \%$ from superficial horizon to the deepest horizon. This accumulation of organic matter is generally followed by an increase in the bulk density of the soil, leading to a stable structure on the topsoil (Table 3). Conventional tillage and minimum tillage yield respectively a density of $1.31 \mathrm{~g} /$ $\mathrm{cm}^{3}$ and $1.26 \mathrm{~g} / \mathrm{cm}^{3}$. On the other hand, the direct seeded soil is distinguished by a value of $1.5 \mathrm{~g} / \mathrm{cm}^{3}$. This result reveals the great variability of the density of a soil subjected to conventional tillage, minimum tillage and direct sowing. The change in $\mathrm{OM}$ and bulk density affects the mode of oxygen and water circulation in soil (Grosman and Reinsch, 2002).

Table 3: Effect of soil tillage on organic matter and soil bulk density

\begin{tabular}{l|c|c|c|c|c|c}
\hline \multirow{2}{*}{ Techniques } & \multicolumn{2}{|c|}{$\mathbf{0 - 8} \mathbf{c m}$} & \multicolumn{2}{c|}{$\mathbf{8 - 3 0} \mathbf{c m}$} & \multicolumn{2}{c}{$\mathbf{3 0 - 4 0} \mathbf{c m}$} \\
\cline { 2 - 7 } & OM & Bd & OM & Bd & OM & Bd \\
\hline DS & $1.99^{\mathrm{a}}$ & $1.29^{f}$ & $1.72^{\mathrm{bcd}}$ & $1.47^{\mathrm{b}}$ & $1.61^{\mathrm{cd}}$ & $1.52^{\mathrm{a}}$ \\
MT & $1.82^{\mathrm{b}}$ & $1.33^{\mathrm{e}}$ & $1.54^{\mathrm{d}}$ & $1.45^{\mathrm{bc}}$ & $1.24^{\mathrm{e}}$ & $1.51^{\mathrm{a}}$ \\
CT & $1.79^{\mathrm{bc}}$ & $1.39^{\mathrm{d}}$ & $0.76^{\mathrm{f}}$ & $1.41^{\mathrm{cd}}$ & $1.24^{\mathrm{e}}$ & $1.51^{\mathrm{a}}$ \\
\hline
\end{tabular}

DS: direct sowing; MT: minimum tillage; CT: conventional tillage; OM: organic matter; Bd: Bulk density

Source: Abdellaoui et al., (2011)

Hydraulic conductivity and soil moisture: Figure 3 shows the evolution of soil moisture in different cropping systems during hard wheat production. The hydraulic conductivity varies from $1.2 \times 10^{-3} \mathrm{~cm} / \mathrm{s}$ for the reduced tillage, $0.72 \times 10^{-4} \mathrm{~cm} / \mathrm{s}$ for conventional tillage and $5.0 \mathrm{x}$ $10^{-4} \mathrm{~cm} / \mathrm{s}$ for no-till soil (Belagrouzet et al., 2016). This soil moisture behaviour is linked to the organic matter, which allows a better ability to store water (Rhyan et al., 2008). Direct sowing and simplified techniques therefore allow better water retention compared to conventional tillage. 


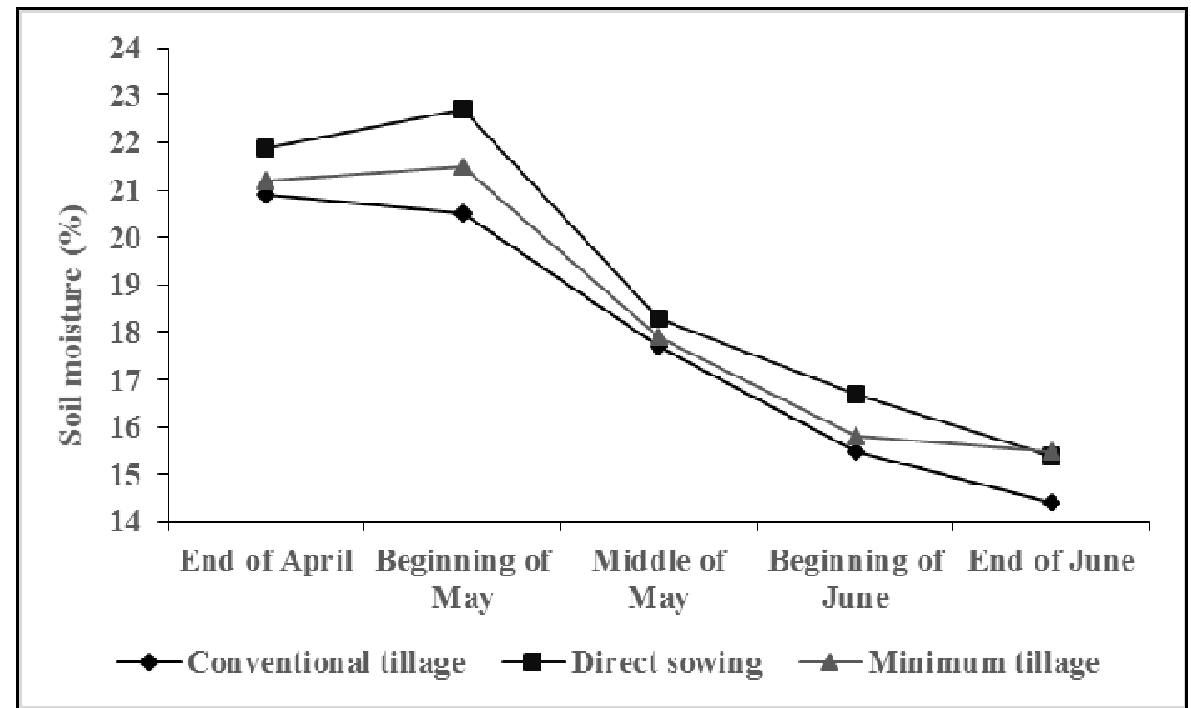

Figure 3: Evolution soil moisture under hard wheat culture (Abdellaoui et al., 2011)

Impacts of different tillages on earthworm population: Figure 4 shows the evolution of earthworm quantities by tillage. Results obtained after 7 years of study by Piron et al. (2011) show that the tillage level reduction facilitates significantly earthworm population growth, especially under direct sowing. This positive effect is more noticed for anecics, biggest earthworms threaten by plough action and their annual habitat destruction. The reduction of tillage appears like a primary element to restore earthworm populations on soil.

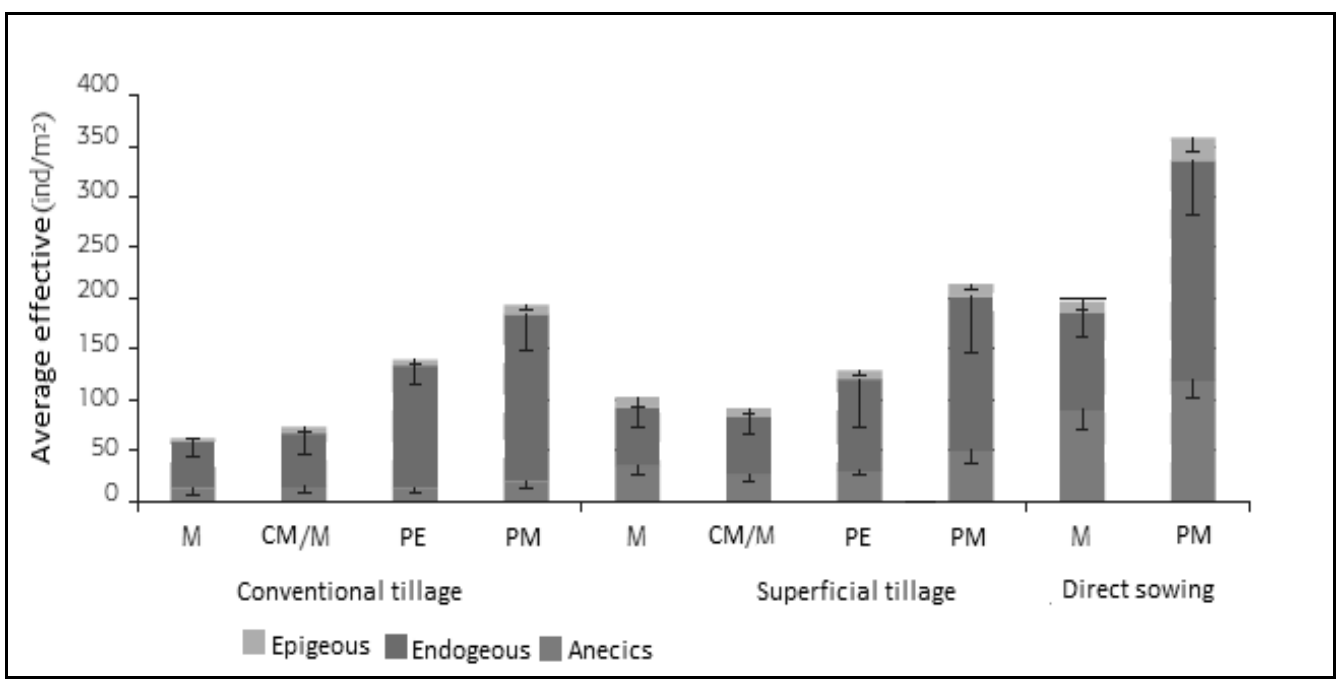

M: mineral; CM / M: cattle manure / mineral; PE: pig excretion; PM: Poultry manure

Figure 4: Influence of the type of tillage on the abundance of earthworms (Piron et al., 2011).

Synthesis of Cultivation Techniques effects on Soil: The main effects of SCT on the soil compared with conventional tillage can be summarized as shown in
Table 4. These effects favour the preservation and increase of soil fertility. This has implications for plant growth and crop yields. 
Table 4: Synthesis of Effects of Simplified Cultivation Techniques and Ploughing on Soil

\begin{tabular}{l|c|c}
\hline Effects on soil & Conventional tillage & SCT \\
\hline Fight against erosion: improvement of structural stability & - & + \\
Surface residues & - & + \\
Soil moisture & + & + \\
Soil temperature & - & - \\
Aeration of surface soil & \pm & + \\
Aeration of the soil on the anthropogenic horizon & \pm & \pm \\
Water infiltration & - & \pm \\
Quantity and protection of soil organic matter & - & + \\
Mineralization of nitrogen & - & + \\
Quantity of soil micro-organisms I & + & - \\
Mushrooms on the surface & - & + \\
Bacteria on the surface & + \\
Quantity of soil macro-organisms & +
\end{tabular}

+: positive effect; - : negative effect; \pm : variable effect (positive or negative) according to the time. Source: Sheperd et al., (2000) cited by Peigné et al., (2005)

Plant development and crop yield: For the same seedling density, the study of the averages reveals a higher percentage of emergences for direct sowing (Table variation between the different cropping systems, with a

Table 5: Mean values of homogeneous groups of variables measured in relation to cropping systems

\begin{tabular}{c|c|c|c}
\hline & $\mathrm{NP} / \mathbf{m}^{2}$ & $\mathrm{NS} / \mathbf{m}^{2}$ & Bio \\
\hline DS & $302.17^{\mathrm{a}}$ & $498.71^{\mathrm{a}}$ & $55.68^{\mathrm{a}}$ \\
SCT & $285.85^{\mathrm{a}}$ & $455.16^{\mathrm{ab}}$ & $44.88^{\mathrm{b}}$ \\
CT & $217.21^{\mathrm{b}}$ & $412.91^{\mathrm{b}}$ & $34.67^{\mathrm{c}}$ \\
\hline
\end{tabular}

Averages followed by the same letter are not significantly different at the 5\% . DS: direct sowing; SCT: simplified cultivation techniques; $\mathrm{CT}$ : conventional tillage; $\mathrm{NP} / \mathrm{m}^{2}=$ number of plants per $\mathrm{m}^{2} ; \mathrm{NS} / \mathrm{m}^{2}=$ number of spikes per $\mathrm{m}^{2} ; \mathrm{Bio}=$ aboveground biomass. Source: Mekhlouf et al., (2011)

The advantage of direct sowing is related to the regularity of the seedling depth, the best location of the fertilizers and the good adhesion of the seed to the soil (Mekhlouf et al., 2011). Table 6 shows the influence of crop practices on agricultural yields. After the 3 rd year of direct sowing, a clear difference is noted on the yield. Zero tillage give the highest yields of $38 \mathrm{q} / \mathrm{ha}$, an increase of $10 \mathrm{q} /$ ha from conventional tillage.

Table 6: Effect of tillage on yield and its components

\begin{tabular}{|c|c|c|c|c|}
\hline & \multicolumn{3}{|c|}{ Yield components } & \multirow[t]{2}{*}{ Yield/ha } \\
\hline & Ears $/ \mathrm{m}^{2}$ & Grains/ears & MWG (g) & \\
\hline MT & 161.75 & $\begin{array}{c}2004 / 05 \text { (year 1) } \\
49.54 \mathrm{ab}\end{array}$ & 41.65 & $11.07 a b$ \\
\hline CT & 171.75 & $53.39 a$ & 42.05 & $13.50^{a}$ \\
\hline DS & 149.5 & $\begin{array}{c}47.87^{b} \\
2006 / 07 \text { (year 3) }\end{array}$ & 39.67 & $10.05^{b}$ \\
\hline MT & $359.83 \mathrm{ab}$ & 54.53 & 29.42 & $35.21 \mathrm{ab}$ \\
\hline CT & $319.83^{b}$ & 57.15 & 30.17 & $28.86^{\mathrm{b}}$ \\
\hline DS & $368.58^{a}$ & $\begin{array}{c}54.83 \\
2008 / 09 \text { (year 5) }\end{array}$ & 29.6 & $38.5^{a}$ \\
\hline MT & 330.58 & 66.90 & 37.95 & $38.18^{b}$ \\
\hline CT & 338.42 & 64.15 & 38.98 & $40.97 a$ \\
\hline DS & 335.08 & 68.43 & 37.08 & $34.97^{\mathrm{b}}$ \\
\hline
\end{tabular}


MT: minimum tillage; $\mathrm{CT}$ : conventional tillage; DS: direct sowing; MWG: middle weight of grains

Source: Abdellaoui et al., (2011)

Table 7 shows the influence of crop practices on the cost of wheat production and income. By opting for direct sowing, the farmer realizes on average a saving of 800 conventional system. The fuel gain is also high (from 22 to $33 \mathrm{I} / \mathrm{ha}$ depending on slope and type of soil) due to a $\mathrm{Dh} / \mathrm{ha}$ for the implantation of wheat compared to the reduction of the number of passages.

Table 7: Technico-economic evaluation of wheat implantation techniques in conventional and no-till crops

\begin{tabular}{|c|c|c|c|c|c|c|}
\hline $\begin{array}{l}\text { Technical itinerary } \\
\text { for wheat } \\
\text { implantation }\end{array}$ & $\begin{array}{c}\text { Time in } \\
\mathrm{h} / \mathrm{ha}\end{array}$ & $\begin{array}{c}\text { Fuel } \\
\text { consumption } \\
\text { in I/ha }\end{array}$ & $\begin{array}{c}\text { Cost of } \\
\text { mechanized } \\
\text { services in Dh/ha }\end{array}$ & $\begin{array}{l}\text { Seeds cost } \\
\text { in Dh/ha } \\
\text { (g/ha) }\end{array}$ & $\begin{array}{c}\text { Mineral fertilizers } \\
\text { in Dh/ha } \\
(\mathrm{g} / \mathrm{ha})\end{array}$ & $\begin{array}{l}\text { Total } \\
\text { cost in } \\
\text { Dh /ha }\end{array}$ \\
\hline \multicolumn{7}{|c|}{ Conventional tillage $(\mathrm{CT})^{*}$} \\
\hline Tillage (disc plough) & 3 to 4 & 10 to 15 & 350 & & \multirow{6}{*}{$\begin{array}{c}480 \\
(150)\end{array}$} & \multirow{6}{*}{2080} \\
\hline $\begin{array}{l}1 \text { rst passage of cover } \\
\text { crop }\end{array}$ & 2 to 2.5 & 10 to 12 & 200 & & & \\
\hline $\begin{array}{l}2^{\text {nd }} \text { passage of } \\
\text { cover crop }\end{array}$ & 1 to 1.5 & 6 to 8 & 200 & & & \\
\hline Seeder & 0.5 to 1 & 5 to 7 & 250 & 600 & & \\
\hline Total CT & 6.5 to 9 & 31 to 45 & 1000 & (200) & & \\
\hline & & & Direct sowing (DS) & & & \\
\hline Herbicidal application & 0.5 & 3 & $70^{\circ}-x \cdot a \cdot x$ & & \multirow{4}{*}{$\begin{array}{c}480 \\
(150)\end{array}$} & \multirow{3}{*}{1280} \\
\hline Direct sowing & 1.25 & 6 to 9 & 250 & 480 & & \\
\hline Total DS & 1.75 & 9 to 12 & 320 & $(160)$ & & \\
\hline $\begin{array}{l}\text { Differences between } \\
\text { DS and CT }\end{array}$ & $\begin{array}{l}-4.75 \text { to } \\
-7.25\end{array}$ & -22 to -33 & -630 & $-220(-40)$ & & -800 \\
\hline
\end{tabular}

A study in Benin on groundnut showed similar results in terms of the profitability of no-till systems (Table 8).

Table 8: Peanut production under different cultivation techniques

\begin{tabular}{l|c|c|c}
\hline & $\begin{array}{c}\text { Minimum tillage with tooth } \\
\text { hoe }\end{array}$ & $\begin{array}{c}\text { Minimum tillage on natural } \\
\text { fallow with tooth hoe }\end{array}$ & Conventional tillage \\
\hline Yield (kg) & 3000 & 2000 & 1500 \\
Expenses (FCFA) & 94500 & 110000 & 113000 \\
Receipts (FCFA) & 300000 & 200000 & 150000 \\
Gross margin (FCFA) & 205500 & 90000 & 37000 \\
\hline
\end{tabular}

Source: Amadji et al., (2007)

Importance of direct seeders and their influence on seed germination and soil moisture: With the exception of the cutting disc placed in front of a direct seeder, the latter, like a conventional seeder, is generally provided with an opener coulter, which opens a furrow into which the seed is introduced. The hopper distributes the seeds at the rate of advance of the seeders by simple mechanical or pneumatic drive. A covering device closes the groove. Direct seeders are specific for successful direct sowing. They are also distinguished by their working bodies. Depending on the shape of the sowing organ, the furrow can take several forms, which influence the rate of seed emergence and soil water retention. Table 9 summarizes the effects of three furrow forms on soil moisture and wheat germination. The results are explained by the fact that the V-shaped groove, implemented by a double-disc has the disadvantage of press residues in the grooves on a wet basis (Friedrich, 2000); causing nitrogen deficiency of the crop and not adequately closing the furrow (drying the seedbed in case of drought after sowing). The U-shaped groove installed from a narrow tooth is more vulnerable to stuffing. The groove due to a tooth $\mathrm{T}$ offers an intermediate position between the first two cases from the perspective of ease 


\section{Dayou et al., J. Appl. Biosci. 2017 Impacts of the conventional tillage tools and reduced tillage on the soil}

fertility preservation: critical review

of penetration ensures higher consistency of sowing depth and shape of the section obtained provides a more favourable microclimate for germination and the emergence at the level of the seedbed (Bourarach, 2011).

Table 9: Influence of the shape of the furrow on soil water loss and germination of wheat

\begin{tabular}{|c|c|c|c|c|c|c|}
\hline & \multicolumn{2}{|c|}{$\begin{array}{l}\text { Furrow in the form of } \\
\text { "V" }\end{array}$} & \multicolumn{2}{|c|}{$\begin{array}{l}\text { Furrow in the form of } \\
\text { "U" }\end{array}$} & \multicolumn{2}{|c|}{$\begin{array}{l}\text { Furrow in the form } \\
\text { of "T"' }\end{array}$} \\
\hline & Wet soil & Dry soil & Wet soil & Dry soil & Wet soil & Dry soil \\
\hline$\%$ of germinated seeds & 42 & 10 & 70 & 31 & 68 & 59 \\
\hline $\begin{array}{l}\text { Germinated seeds which don't reach the soil } \\
\text { surface }\end{array}$ & 58 & 72 & 30 & 22 & 32 & 23 \\
\hline $\begin{array}{l}\text { Non germinated seeds } \\
\text { Loss of relative soil relative humidity (\%) }\end{array}$ & 0 & 18 & 0 & 47 & 0 & 18 \\
\hline
\end{tabular}

Source: Baker et al., (1996)

\section{DISCUSSION}

Soil organic matter: Organic matter plays an important role in the structure and protection of soils against degradation agents. Its decomposition is quite sensitive to environmental conditions and changes in agricultural management practices. Mrabet (2001a) found that the rate of organic matter evolves remarkably under direct sowing as a function of time, while under conventional tillage; the soil retains substantially the same contents. Ben Hammouda et al. (2004) also asserted after 3-year experiment that no-till increases organic matter in the soil, $2.6 \%$ against $2.3 \%$ measured in conventional mode. Mrabet (2004) adds that only direct sowing improves soil organic matter level after comparing the use of different farming tools with zero tillage. However, it is difficult to assess the impact of OM from a single point of view, given the strong interaction with all soil characteristics (Fagaye et al., 2013). In all cases, Bourguignon (2004) reveals that organic matter increases by $0.3 \%$ in the first year to the third year of direct sowing on clay soil.

Soil moisture and density: A comparative study of soil water dynamics between direct and conventional sowing by Nouiri et al. (2004) has shown that no-till enhances water intake by preserving the quantity of water present in the soil with a difference of $5 \%$ in its favour. This is because soil conservation techniques help first to protect the soil from structural accidents, the formation of mulch increases the density of the topsoil. This has the effect of improving the resistance of the soil to compaction and of limiting the soil slaking (Almaricet et al., 2008). Soil moisture changes from $5.8 \%$ to $12.7 \%$ in tillage and from $10.6 \%$ to $17.3 \%$ in direct sowing on clayey-limestone soils, confirming that no-till under vegetal cover retains more moisture in the soil especially after a few years of direct sowing. This is fundamental in countries where water is the main limiting factor in agricultural production.
Moreover, the surface of a soil in direct sowing is transformed with time into a living carpet, which remains practicable even under unfavourable conditions. Indeed, this surface not disrupted by the tillage tools maintains a structural stability superior to a surface ploughed during the year. Thus, the no-till soil remains better aggregated opposite to the climate hazards and the desiccationmoistening cycle. However, decreased surface roughness can lead to increased runoff risks (Almaric et al., 2008, Carof, 2006, Peigne et al., 2009).

Improvement of soil fertility: Several studies have shown that no-till facilitate an increase in the carbon stock in the early soil horizons and an increase in the quantity, activity and diversity of microorganisms (Ibekwe et al., 2002). Bohlen et al., (1995) show that tillage stopping is accompanied by an increase in earthworm densities, which favours macroporosity of biological origin. Leguminous plants are inserted for the production of straw, or as a main crop for seed production, but also to increase the nitrogen content in the soil, taking into account the characteristic of leguminous to fix nitrogen (Fagaye et al., 2013). Direct sowing conserves the high levels of organic matter that are fundamental to preserve the potential capacity of soils (Xanxo et al., 2006).

Agricultural productivity: Comparison of the behaviour of hard wheat crop under different tillage methods shows that the grain yield was better expressed in conventional driving, reflecting decreases of $26 \%$ and $18 \%$, respectively, in the no-till and the Minimum work. After the 3 rd year, driving in no tillage exceeded the yields obtained in conventional system by $10 \mathrm{q} / \mathrm{ha}$ (Abdellaoui et al., 2011). In addition, Chervetet et al. (2005) found that emergence is often less good in direct sowing because of slug damage. Hemmat and Eskandari, (2006) report that the grain performance of minimum and no-till was 25 to 
$42 \%$ higher than that conventional tillage. These authors note that the number of ears of no-till and minimum tillage was significantly higher, while the number of grain per ears was higher in conventional tillage. However, the tillage methods had no significant effect on the weight of 1000 grains. The good results of minimum tillage and direct sowing are due to more soil moisture availability under these two modes of management compared to conventional tillage (Hemmat and Eskandari, 2006). All of the above shows the need to move from conventional tillage to direct sowing.

Critical analysis of seeders in direct sowing: Based on the traction force, the direct seeder can be divided into three groups: manual, animal traction and motorized traction. Despite their contribution to direct sowing, the use of manual seeder requires time and a lot of physical force when the soil has not been ploughed. There are also problems of clump of grass, poor grain spacing, low overlap and therefore a low rate of emergence (Sims, 2014; Johansen et al., 2012). For animal traction, these seeders are often fragile, poorly crossed the mulch and are prone to a clump of grass (Rachou, 1997). Their use is limited if the amount of residues on the soil is greater than $5 \mathrm{t} / \mathrm{ha}$ (Morrison, 2009). Another weakness of these seeders in addition to their low weight makes it difficult to control seeding depth (Jin et al., 2014). In motorized traction, direct seeders appear to be used for farms with a large area, given the tractor power they require. Usage costs are high in small areas. In order to be successful in zero tillage, it is essential to have a seeder that can cope with the variability of soil conditions on the same day, in the same plot and between plots (FAO and CAB International, 2007). The seeder should have heavy opening discs for better penetration of the tools into hard soil, as well as debris to avoid accumulation of residues in the furrow that would prevent seed-soil contact (Coutant et al., 2012). Residue management is therefore crucial to the success of direct sowing. Poor cutting can conduct to residue accumulations on the various parts of the seeder, causing seed and fertilizer problems: irregular spacing or total absence of seed (Ribeira et al., 1999). For good results, it is recommended to work during the hours of the

\section{CONCLUSION}

This critical synthesis has made it possible to explain the impacts of both conventional tillage and simplified cultivation techniques on soil fertility and agricultural production. It is observed that conventional techniques induce long-term disturbance of soil properties and reduce fertility. Simplified cultivation techniques and direct day when the temperature is the highest, to conduct the operation when the stems are either still green or completely dry. Instead of cutting the residue, the solution of moving them away from the seed line can be adopted: "sun wheel" with flexible teeth (Morrison, 2009). Thus, soil characteristics and the types of residues to be cut deserve special attention at the level of direct seeder. However, improvements need to be made to the equipment to accompany the extension of direct sowing. Indeed, the technologies to accompany conservation agriculture are very poorly introduced in many African countries, and are almost non-existent in Benin. The lack of appropriate materials and knowledge by producers are the main reasons for this (Karabayev et al., 2012). The main failures of motorized seeders can be summarized as follows:

- $\quad$ a bad cut of the residues especially if they are faded;

- the lack of precision of the coulters both in depth and on the seeding line if driving at more than 7 to $8 \mathrm{~km} /$ $\mathrm{h}$; furrows;

irregular space or total absence of seeds in the

- $\quad$ straw-seed contact problems;

- $\quad$ stuffing problems especially for tooth seeders;

- $\quad$ the complexity of the adjustments;

- $\quad$ the excessive weight of the seeders;

- $\quad$ problems of penetration into too dry soil and closing of furrows in too moist soil;

- low rate of emergence when the amount of residues on the soil is greater than $10 \mathrm{t} / \mathrm{ha}$;

In addition to these challenges, the new seeder must also:

- have good behaviour in clay and loam soils or in the presence of pebbles while being precise;

- be mono grain with the possibility of choosing the gap between the rows;

- have a good distribution and closure of the furrows with a speed of 8 to $12 \mathrm{~km} / \mathrm{h}$;

- $\quad$ make a normal compaction behind the seed;

- $\quad$ be easy to adjust;

- $\quad$ easy to hitch and to unharness.

sowing have shown a positive effect on the amount of soil organic matter, its density and water retention, and final production. Of all simplified cultivation techniques, direct sowing brings more organic matter especially for the protection of the soil against the weather. However, its 
installation in field crop requires specific direct seeder that it is urgent to design.

\section{ACKNOWLEDGEMENT}

This research was supported by the International Foundation for Science, Sweden, through a research grant to DAYOU Ephrème Dossavi.

\section{REFERENCES}

Abdellaoui Z, Teskrat H, Belhadj A, Zaghouane O, 2011. Étude comparative de l'effet du travail conventionnel, semis direct et travail minimum sur le comportement d'une culture de blé dur dans la zone subhumide. In : Bouzerzour $\mathrm{H}$. (ed.), Irekti H. (ed.), Vadon B. (ed.). 4. Rencontres Méditerranéennes du Semis Direct. Zaragoza : CIHEAM / ATU-PAM / INRAA / ITGC / FERT, 2011. p71-87.

Aboudraré A, 2009. Agronomie durable: principles et pratiques. Reinforcement des capacités locales pour developer les produits de qualité de montagne - Cas du safran. Rapport de formation continue. FAO/TCP/MOR/3201(D). 46p.

Almaric N, Brezillon M, Faiq CRE, Schroeder M, Tite A, 2008. « La vulgarisation de l'agro-écologie : de la théorie au terrain ». Octobre 2008 Projet INPENSAT/Solagro. PP 1-4.

Amadji F, Adjé I, Maliki R, Téblékou K, 2007. Promotion des systèmes de semis direct sous couverture végétale au Bénin : état des lieux, travaux de terrain et perspectives. INRAB/RD Savè, Collines. 65p.

Andrade DS, Colozzi-Filho A, Giller KE, 2003. The soil microbial community and soil tillage. In: A. El Titi (Ed.), Soil Tillage in Agroecosystems, CRC Press LLC Boca Raton, p. 51-81.

Baker CJ, Saxton KE, Ritchie WR, 1996. No-tillage seeding. Science and practice. $C A B$ International, University Press Cambridge. 258pp.

Belagrouz A, Chennafi H, Hakimi M, Soualili N, Razem R, Boutalbi W, Ferras K, 2016.Conductivité hydraulique et densité apparente sous labours de conservation du Sol. Revue Agriculture Numéro spécial 1 (2016) 100-105

Bellemou A, 2012. Étude des résultats d'essais de différentes techniques de semis du blé dur (Chen's). Thèse en vue de l'obtention du diplôme de Magister en Sciences
Agronomiques. École Nationale Supérieure Agronomique El-Harrach-Alger. 152p.

Ben Hammouda M, Guesmi L, Nasr K, Khammassi M, 2004. Évolution de la matière organique en semis direct. Dans : Actes des deuxièmes rencontres méditerranéennes sur le semis direct, Tunisie, pp104-107.

Blanchart E, Bernoux M, Siqueira Neto M, Cerri CC, Piccolo M, Douzet JM, Scopel E, Feller C, 2009. Effet des systèmes de semis direct sous couverture végétale (SCV) sur le stockage de carbone et la macrofaune d'un sol ferralitique (Cerrados, Brésil). Étude et Gestion des Sols, Vol 16, 1, 2009-p35-46

Blanchart E, Barthes B, Bernoux M, Chapuis-Lardy L, Chotte JL, Coq S, Douzet JM, Falinirina V, Feller C, Rabary B, Randriamanantsoa R, Ratnadass A, Razafimbelo T, Scopel E, Villenave C, Weber $L, 2008$. Fonctionnement du sol sous SCV au Brésil et à Madagascar: Abondance et rôle des ingénieurs du sol sur la dynamique du carbone du sol. Symposium 2 : Diversité et abondance des organismes du sol. pp40-43.

Bohlen PJ, Edwards WM, Edwards CA, 1995. Earthworm community structure and diversity in experimental agricultural watersheds in Northeastern Ohio. The significance and regulation of soil biodiversity. Plant and Soil 170 , 233-239.

Bourarach EH, 2011. Equipements utilisés en agriculture de conservation. HTE N ${ }^{\circ}$ 149/150-Sept/Déc 2011. p29-34.

Bourarach EH. et Oussiblé M, 2001. Technique de production végétale et environnement. Revue H.T.E. No 119. Juin 2001. $7 p$.

Bouzza A, 1990. Water conservation in wheat rotations under several management and tillage systems in semi-arid areas. PhD Dissertation, University of Nebraska, Lincoln, NE.

Carof M, 2006. Fonctionnement de peuplements en semis direct associant du blé tendre d'hiver 
(Triticum aestivum L.) à différentes plantes de couverture en climat tempéré. Thèse présentée pour l'obtention du titre de docteur de l'institut national agronomique Paris. Grignon. P 115.

Chervet A, Ramseier L, Sturny WG, 2005. Comparaison du semis direct et du labour pendant 10 ans. Revue suisse Agric. 37 (6): 249-256, 2005.

Coutant F, Schreiber K, Solon B, 2012. Matériel pour le semis direct, 1ère journée de rencontre : " couverts végétaux et semis direct " _ Auch_10 fév. 2012.

Fagaye S. et al., 2013. Système de semis direct sous couverture végétale : manuel de bonnes pratiques agricoles sur le cotton. Embrapa, Brésil. 88p.

FAO, 2011. Machinisme, outils et équipements. Département de l'agriculture et de la protection des consommateurs. HTE $N^{\circ}$ 149/150 Sept/Déc 2011. pp71-105.

FAO and CAB International, 2007. No-tillage seeding in Conservation Agriculture, 2nd edn. (eds C.J. Baker and K.E. Saxton). 341p.

Friedrich T, 2000. Conceptos y objetivos de la labranza en una agricultura conservacionista. In: Manual de prácticas integradas de manejo y conservación de suelos. FAO. Soil and Water Bulletin 8. Rome. pp29-37.

Grosman RB. and Reinsch TG, 2002. Bulk density and linear extensibility. In: J.H dane and G.C. Topp, Eds. Methods of Soil Analysis, Part 4- Physical Methodes. Soil science society of America, Madison WI, pp201-228.

Hemmat A. and Eskandari I, 2006. Dryland winter wheat response to conservation tillage in a continuous cropping system in northwestern Iran. Soil\& Tillage Research86: 99-109.

Ibekwe AM, Kennedy AC, Frohne PS, Papiernik SK, Yang $\mathrm{CH}$, Crowley DE, 2002. Microbial diversity along a transect of agronomic zones. FEMS Microbiology Ecology 39, 183-191.

Jin H, Zhiqiang Z, Hongwen L, Qingje W, 2014. Development of small/medium size no-till and minimum-till seeders in Asia: a review. In: Int $\mathrm{J}$ Agric and Biol Eng, Vol. $7 \mathrm{~N}^{\circ}$ 4. August 2014. $12 p$.

Johansen C, Haqueb ME, Bell RW, Thierfelderd C, Esdaile RJ, 2012. Conservation agriculture for smallholder rainfed farming: Opportunities and constraints of new mechanized seeding systems. Field Crops Research 132 (2012) 1832

Karabayev M, Wall P, Sayre K, Morgounov A, 2012. Conservation agriculture adoption in Kazakhstan: History, Status and Outlooks. CIMMYT Report.

Kribaa MV, Hallaire J, Curmi P, Lahmar R, 2001. Effect of various cultivation methods on the structure and hydraulic properties of a soil in a semi-arid climate. Soil Till Res $2001 ; 60: 43-53$.

Labbaci T, Dugué P, Kemoun H, Rollin D, 2015. Innovation et action collective : le semis direct des cultures pluviales au Moyen Sébou (Maroc). Cah Agric 24 : 76-83.

Le Garrec L. et Revel A, 2004. Le non-labour en grandes cultures et élevage : évaluations environnementales et économiques à l'aide de la marge directe des indicateurs Deltameq et Indigo. Ingénieries N³8-p.21 à 35. Juin 2004.

Lal R, Reicosky DC, Hanson JD, 2007. Evolution of the plow over 10,000 years and the rationale for a no-till farming. Soil Till Res93: 1-12.

Mekhlouf A, Makhlouf M, Achiri A, Ait Ouali A, Kourougli S, 2011. Étude comparative de l'éffet des systèmes de travail du sol et des précédents culturaux sur le sol et le comportement du blé tendre (Triticum aestivum L.) en conditions semiarides. Agriculture $\mathrm{N}^{\circ} 2$ 2, 2011, 52-65.

Morrison JE, 2009. Simple CA Implements. ISTRO 18th Triennial Conference Proceedings, June 15-19, 2009 Izmir-Turkey.

Mrabet R, 2004. Le système de semis direct en milieu semi-aride marocain : Aperçu sur les acquis de la recherché. Dans: Actes des deuxièmes rencontres méditerranéennes sur le semis direct. Tunisie.

Mrabet R, 2001a. Le Semis Direct: Une technologie avancée pour une Agriculture durable au Maroc. Bulletin de Transfert de Technologie en Agriculture du PNTTA. MADREF/DERD. $N^{\circ} 76$, Janvier 2001. 4p.

Nouiri I, M'hedbi K, Ben Hammouda M, Kammassi M, Neit El Arbi S, Ali Hannachi M, Guesmi L, Mannai C, Hajji S, 2004. Étude comparative de l'humidité des horizons du sol entre le semis direct et le semis conventionnel. Dans : Actes des deuxièmes rencontres méditerranéennes sur le semis direct. Tunisie.

Peigné J, Védie H, Demeusy J, Gerber M, Vian JF, Gautronneau Y, Cannavaccuiolo M, Aveline A, 
Giteau LL, Berry D, 2009. Techniques sans labour en agriculture biologique. Innovations Agronomiques (2009) 4, 23-32.

Peigné J, Gautronneau Y, Cannavacciuolo M, Aveline A, 2005. Les techniques culturales simplifiées en agriculture biologique. Agronomie $n^{\circ} 70$, mars/avril 2005, 11-14.

Piron D, Rougé L, Bispo A, Grand C, Galsomies L, Cluzeau D, 2011. The use of earthworms as tool for soil monitoring, characterization and risk assessment. Example of a Bioindicator Programme developed at National scale (France). Pedobiologia 54:77-87.

Rachou M, 1997. Semis direct en traction animale dans l'Etat du Parana, Brésil. Mémoire EITARCCNEARC, Montpellier, $115 \mathrm{p}$.

Ribeira MFS, Araújo AG, Casão RJ, Benassi DA, 1999. Máquinas para semeadura direta em solos de baixa aptidão agrícola. In: Uso e manejo do solos de baixa aptidão agrícola. Muzilli and Castro Filho (Eds.) IAPAR Circular Técnica 108. p139-152.

Rhyan J, Masri S, Ibrikci H, Singh M, Pala M, Harris HC, 2008. Implication of cereal based crop rotation nitrogen fertilisation and stubble grazing on soil organic matter in a Mediterranean type environment. Dans: Turk J. Agriculture and forestry, 32, pp. 289-297.

Sims B, 2014. Agriculture for development. In: Tropical agriculture association. No. 21, Spring 2014.p13.

Xanxo L, Solans A, Cantero-Martínez C, 2006. Système de production de cultures fourragères en semis direct dans la zone de la Seu d'Urgell, à Lleida, en Espagne. Options Méditerranéennes, Série A, Numéro 69. pp27-36. 